\title{
Research Paper \\ Investigating the Prevalence and Etiology of Accidents Recorded at Emergency Management Center of Gonabad City Using the Pareto Chart in 2018
}

\author{
Mohammad Hossein Beheshti ${ }^{1}$ (1), Mojtaba Amkani ${ }^{1}$, Amin Zamani ${ }^{2}$, Akram Tabrizi ${ }^{3}$, ${ }^{*}$ Mostafa Jafari ${ }^{4}$ (1)
}

1. Department of Occupational Health Engineering, Social Development and Health Promotion Research Center, Gonabad University of Medical Sciences, Gonabad, Iran.

2. Department of Emergency Medicine, School of Nursing and Midwifery, Social Factors Affecting Health Research Center, Gonabad University of Medical Sciences, Gonabad, Iran.

3. Department of Occupational Health Engineering, School of Health, Tehran University of Medical Sciences, Tehran, Iran.

4. Department of Occupational Health Engineering, School of Health, Gonabad University of Medical Sciences, Gonabad, Iran

$\begin{aligned} & \text { Use your device to scan } \\ & \text { and read the article online }\end{aligned}$
$\begin{aligned} & \text { corded at Emergency Management Center of Gonabad City Using the Pareto Chart in } 2018 \text { (Persian)]. Quarterly of "The Horizon } \\ & \text { of Medical Sciences". 2021; 27(1):48-61. https://doi.org/10.32598/hms.27.1.3348.1 }\end{aligned}$
dol https://doi.org/10.32598/hms.27.1.3348.1

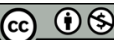

Received: 11 Feb 2020 Accepted: 21 Jul 2020 Available Online: 01 Jan 2021

Key words:

Pareto chart, Emergency hospital service, Accident

\section{A B STRACT}

Aims Accidents are the leading causes of hospitalization and death. This study investigates the prevalence and causes of accidents recorded in Gonabad City emergency hospital service using the Pareto chart from 2016 to 2018.

Methods \& Materials This descriptive and analytic study reviewed about 12281 emergencies recorded during 2016-2018, and the key variables such as the number of incidents, causes of incidents, age, gender, and time of incidents were collected for transport and non-transport incidents. Data analysis was performed using a Pareto chart in Minitab V. 16, SPSS V. 18, and EXCEL 2010.

Findings Based on the results, the highest rate of the incidents (542 cases) was related to falling and the lowest related to chemical and electrical burns with one case. Also, most complaints were related to accidents. In the present study, the rate of road accidents was higher than the street and urban accidents ( 8142 and 4208 cases, respectively). The most frequent accidents were related to motorcycles (748 cases) and then light vehicles (744 cases). The number of accidents that occurred in September and April is higher. Most male victims of accidents were between 16 and 20 years old.

Conclusion Since incidents related to the fall and clash with the mechanical force have the highest prevalence, it is necessary to allocate more financial and human resources to prevent such accidents. Because most admissions to emergency hospital services are related to accidents, and the rate of road accidents is high, it is essential to investigate the causes of accidents. Then, it is possible to raise public awareness to respect the safety regulations while driving and increasing the quality of roads.

\section{Extended Abstract}

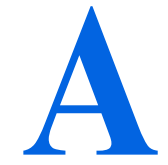

\section{Introduction}

ccidents are one of the leading causes of non-communicable diseases $[1,2]$, which are no longer considered as a random phenomenon but are a price that humans have to pay for the advancement of technology. Accidents, as the second leading cause of disability, can lead to physical and mental disorders and, in severe cases, even death [3]. Traffic accidents are the eighth

\section{* Corresponding Author:}

Mostafa Jafari

Address: Department of Occupational Health Engineering, School of Health, Gonabad University of Medical Sciences, Gonabad, Iran.

Tel: +98 (915) 7357645

E-mail: m.jafarizaveh97@gmail.com 
leading cause of death globally, and the first leading cause of death in the age group of 15-29 years [4].

According to the World Health Organization, the number of deaths due to traffic accidents will increase by $80 \%$ from 2000 to 2020 [5]. According to studies, about 9 million accidents occur every year, and accidents are among the leading causes of hospitalization and death. According to published statistics, various injuries caused by accidents account for 3\% of all visits to medical centers in Iran [6]. Every year, more than 5 million people in the world die due to injuries caused by accidents, and tens of millions of people go to emergency departments for reasons such as accidents, drownings, falls, violence, electric shocks, bites, suicides, etc. Besides hurting people's health, traffic accidents incur costs related to care and treatment and rehabilitation needs and have a psychological effect on people [7].

Vehicle accidents are considered a very serious issue and are inevitable consequences of traffic and road transport [5]. Motorcycle crashes account for a significant number of all accidents worldwide. More than $51 \%$ of traffic accidents that lead to death or hospitalization are related to motorcyclists in Iran $[8,9]$.

In a few studies, Pareto charts have been used to identify and prioritize problems in various contexts. Pareto chart (Pareto analysis) is a way to manage errors and shortcomings to focus on problem solving. This chart is based on the work of the $19^{\text {th }}$-century economist Wilfredo Pareto. Joseph M. Juran generalized Pareto's principle by stating that $80 \%$ of a company's problems are the result of only $20 \%$ of the causes [10]. Pareto chart is used to identify the issues and topics that have caused the highest share of problems. The primary purpose of using a Pareto chart is to create a system that can automatically audit and modify. In this study, the frequency and causes of accidents registered in Gonabad City's Medical Emergency and Accident Management Center in 2018 based on the Pareto chart were investigated.

\section{Materials and Methods}

This research was a cross-sectional descriptive study in which all accidents registered in Gonabad City's Medical Emergency and Accident Management Center in 2018 were examined based on the Pareto chart. This chart represents frequency distribution for descriptive data, which are classified by groups. The horizontal axis of this chart shows the categories, and its vertical axis shows the frequency or percentage of observations of each category. This method determines the area in which the most problems (80\%) are located. The Pareto chart identifies essential factors leading to a "defect" or "defect in a process" [11].

After determining the frequency of influential factors, a chart is drawn based on their frequencies and percentages of inclusion. To obtain frequencies, it is necessary to prepare an accident register form based on the required information and analyze them. Although all actions and calculations can be done manually, using the right software increases the speed and accuracy of the job. The two most widely used applications in this field are SPSS and Minitab.

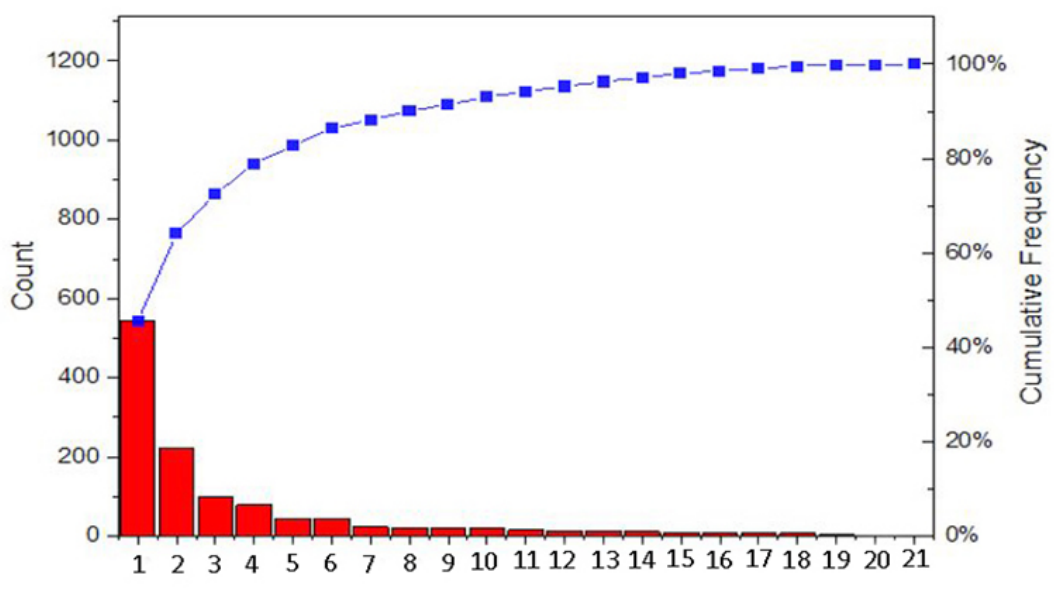

Figure 1. Results of accident investigation by the "type of accident"

Quarterly of

The Horizon of Medical Sciences

1. Falls from heights; 2. Hit by mechanical force; 3. Bites with insects or reptiles; 4. Medicine poisoning; 5. Drug poisoning; 6. Violence; 7. Burns with hot liquids; 8 . Common cold; 9. Animal bites; 10. CO poisoning; 11. Respiratory obstruction; 12. Electric shock; 13. Toxic poisoning; 14. Other cases; 15. Fire burns; 16. Alcohol poisoning; 17. Other burns; 18. Suicide; 19. Heatstroke; 20. Electric burns; 21. chemical burns. 


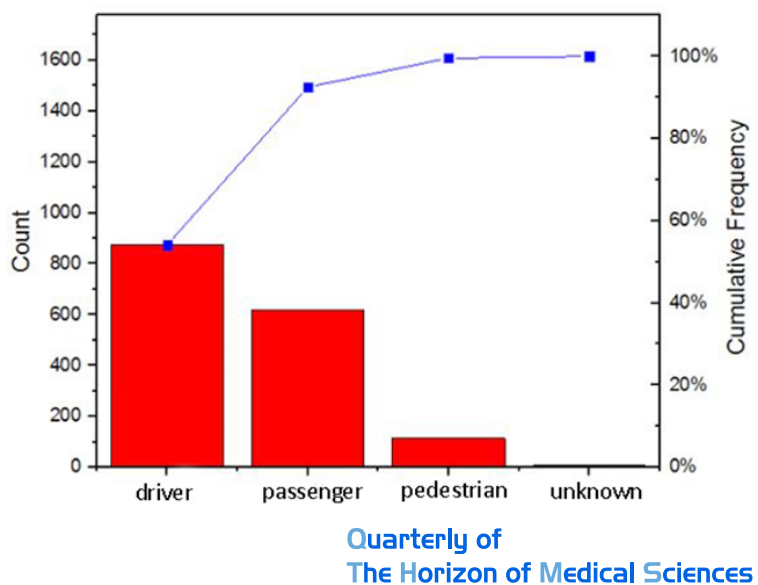

Figure 2. Results of accident investigation by the "injured situation"

In this study, information about all accidents in 2018 was examined. These variables included the number of accidents, causes of the accidents, gender and age of victims, time of the accident, marital status, location of the accident, injured body part, drugs used in transport, and non-transport accidents. They were collected and then analyzed in Minitab16, SPSS V. 18, and EXCEL V. 2010 applications.

\section{Results}

According to the present study results, a total of $12281 \mathrm{ac}-$ cidents and medical emergencies were recorded in Gonabad City in 2018, of which 4174 were urban, and 8107 were road accidents. Also, the results of accident investigation by the "type of accident" are shown in Figure 1.

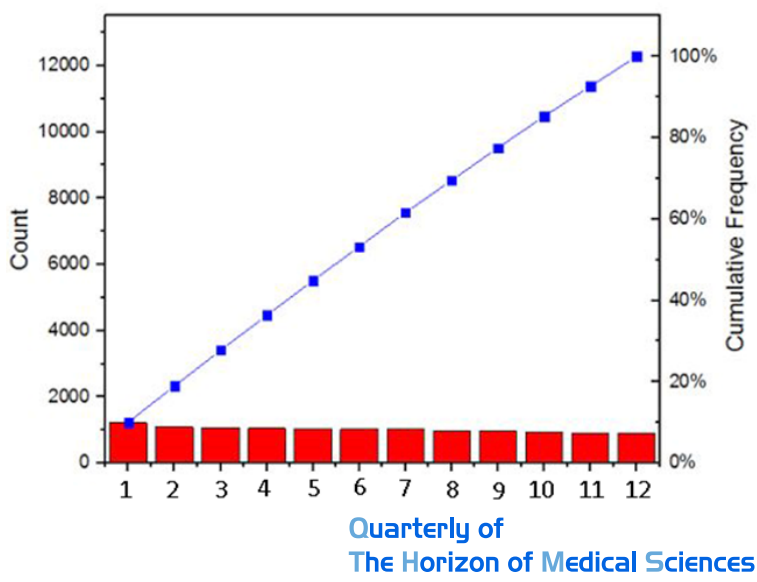

Figure 4. Results of accident investigation by the "month of the year"

1. September; 2. April; 3. November; 4. August; 5. January; 6. December; 7. June; 8. March; 9. October; 10. February; 11. July; 12. May.

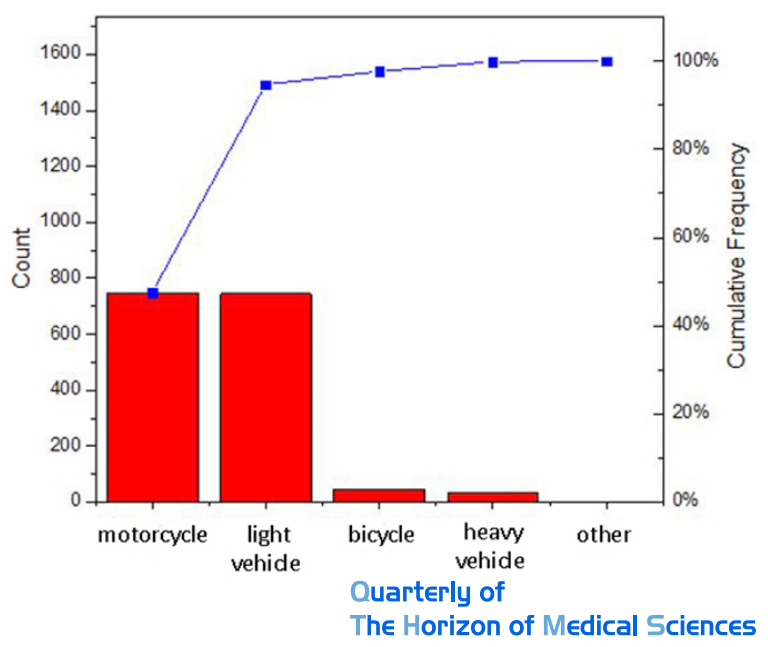

Figure 3. Results of accident investigation by the "type of vehicle"

As the results show, "chemical and electrical burns" with one case had the lowest number of accidents, and "falls from heights" with 542 cases $(46 \%)$ and "collision with mechanical force" with 222 cases (19\%) had the highest number of accidents. The results of investigating traffic accidents by the "condition of injured person" are shown in Figure 2, and by the "vehicle type" in Figure 3.

According to Figure 4, the results showed that the highest number of accidents occurred in September and April, and the lowest number of accidents occurred in July and May. The results of the investigation of accidents by age of the injured are shown in Figure 5.

The results also showed that most people referred to the emergency medical center were related to "accident" with 1903 cases $(15.5 \%)$ and then to "collision with mechanical force" with 1616 cases (13.1\%). "Fire" with one case $(0.008 \%)$ had the lowest number of accidents (Figure 6). Also, the number of accidents in males was higher than females (55.3\% and $44.7 \%$, respectively).

\section{Discussion}

According to the results of this study, more than $60 \%$ of emergencies were related to the "fall from heights" and "collisions with mechanical force", and the least to "chemical burns and electrical burns". Also, most of the complaints of people referring to the emergency medical centers were related to "accidents". The results of the study of Beheshti et al. which was conducted with the same title but from 2013 to 2016, were also consistent with the results of the present study [12]. In the study of Khatibi et al. (2007), most cases were related to "traffic accidents" $(42 \%)$ and the least to "electric shocks" $(0.2 \%)[3]$. Also, in Hamid Souri's study (2001), the epidemiology of accidents 


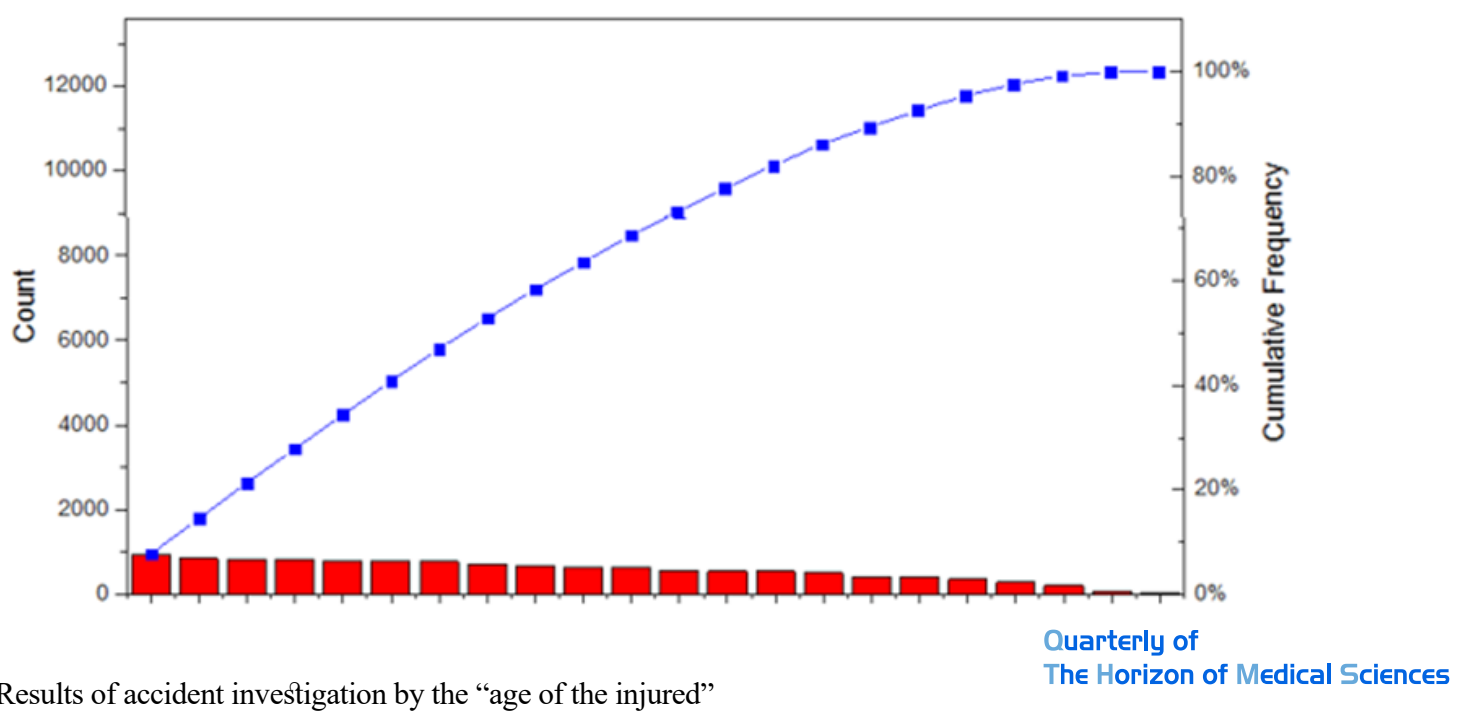

Figure 5. Results of accident investigation by the "age of the injured"

Between 16 and 20, between 26 and 30, between 31 and 35, between 46 and 50, unspecified, between 36 and 40, between 21 and 25 , between 56 and 60 , between 41 and 45 , between 61 and 65 , between 81 and 85 , between 76 and 80 , between 51 and 55 , between 71 and 75, between 66 and 70, between 11 and 15, less than 5 years, between 86 and 90, between 6 and 10, between 91 and 95 , between 95 and 100, more than 100 .

in children referred to the emergency department of Ahvaz hospitals proved that "trauma caused by various objects" $(37.2 \%)$, "falls from heights" (22.8\%), and "traffic accidents" $(10.6 \%)$ were the leading causes of the injuries [13].

In the study of Koohpaei et al. in Gonabad City (20142016), "traffic accidents" accounted for $17.61 \%$ and "heart accidents" for $10.92 \%$ of the total number of accidents
[14]. According to the present study results and its comparison with the results of the Koohpaei et al. study, traffic accidents have increased significantly in recent years, the essential type of which is "falls from heights". In the study of Masoud Mohammadi et al. (2016), both men and women had the highest frequency. The percentage of accidents were as follows: "car accident" with 758 cases (30.9\%),

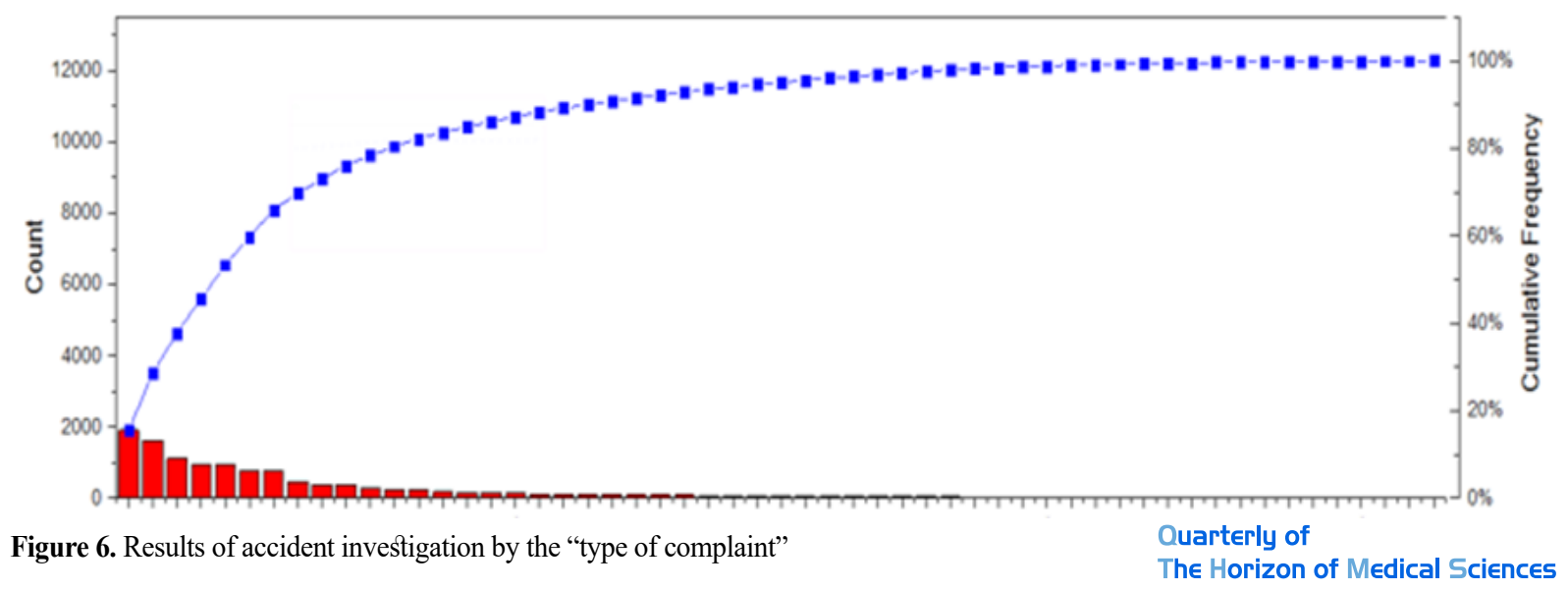

Accident; weakness and lethargy; other cases; heart disease; hypertension; non-accidental trauma; shortness of breath; abdominal pain; chest pain; seizure; renal colic; impaired consciousness; falls from heights; diabetes; dizziness; pregnancy problems; gastrointestinal; decreased level of consciousness; ambiguous abdominal pain; headache; childbirth; drug poisoning; scorpion bite; low back pain; trauma; head trauma; cardiopulmonary arrest; bleeding from the nose; poisoning; women's emergency; internal; allergy; mental disorder; unspecified; burns; possibly stroke; airway obstruction; gastrointestinal bleeding; muscle cramps; hypertension; gas poisoning; bleeding; electric shock; co poisoning; toxic poisoning; asthma attack; vaginal bleeding; knife wound; shot; methadone poisoning; drug abuse; animal bites; abortion; cancer; patient death. 
"violence" with 323 cases (11.9\%), and "suicide" with 121 cases $(10.9 \%)[6]$.

In the study of Ghahraman Mahmoudi et al. (2013), most deaths were related to "road accidents", and after "traffic accidents", the "falls from heights" had the highest rate of injury, which is consistent with the results of the present study [7]. In the study of Ahmadpour et al. (2009) in Qazvin City, Iran, the highest rate of accidents was related to traffic accidents (38.1\%), and the lowest rate to suicide $(0.8 \%)$ [15]. All of the above study results are consistent with the present study results, which accounted for the highest rate of traffic accidents.

In the present study, drivers accounted for $55 \%$, occupants $40 \%$, and pedestrians $8 \%$ of the victims of accidents. In the study of Seyed Saeed Hashemi Nazari et al. (2012), the situation of people who died during the accident showed that the incidence of deaths were as follows: pedestrians 324 cases $(24.36 \%)$, passengers 419 cases $(31.5 \%)$, drivers 569 cases (42.78\%), and unknown 18 cases (1.35\%) [16]. Also, in the study of Payman Asadi et al. the most injured in traffic accidents were motorcyclists and car occupants [17]. In the study of Seyed Saeed Hashemi Nazari et al. (2012), the results showed that the incidence of mortality in drivers $(42.78 \%)$ is the highest [16]. The results of all these studies confirm the results of the present study in the sense that drivers have the highest number of injured.

The highest rate of accidents is related to motorcycles (more than $45 \%$ ), and then light vehicles (more than $45 \%$ ), which is consistent with the study results of Payman Asadi and associates. Also, in the study of Seyed Saeed Hashemi Nazari et al. $47.9 \%$ of the deceased used cars and vans, 43.6\% motorcycles and bicycles, and $8.5 \%$ heavy vehicles [16]. Kazem Alizadeh Barzian, in his study, showed that out of 55108 accidents resulting in injuries in Behbahan City, Iran, $48.5 \%$ are related to traffic accidents, the highest of which is related to motorcyclists (58.8\%) [18].

Teaching traffic rules through public media has a significant role in increasing public awareness. Awareness of people about the importance of observing safety regulations while driving and improving the quality of streets effectively reduces accidents. In the present study, the rate of road accidents was higher than the street (urban) accidents (65\% and $35 \%$, respectively). This finding could be due to non-compliance with the speed limit on suburban roads, lack of warning signs in accident hotspots, insufficient rest before driving, continuous driving over long distances, etc. The number of accidents can be reduced by educating preventive measures, paying more attention to road safety, and increasing police control.
In the study of traffic accidents in Ethiopia (2008), the main factors influencing the number, causes, and possible interventions of accidents were poor road network, lack of awareness about road traffic safety, mixed traffic flow system, lack of rules to put pressure on drivers, unsuitable vehicle conditions, poor emergency medical services, and the absence of compulsory insurance law on traffic accidents [19]. Also, in the study of Ansari et al. (2000), the results showed that more than $65 \%$ of accidents were due to vehicles traveling too fast or drivers disobeying traffic signs [20]. In Ahmadpour's study, the number of accidents on suburban and urban roads was equal (18\%), which was mainly related to automobiles (20.6\%) [15]. In Asadi's study, most accidents (53.1\%) were on suburban roads [17].

In the present study, the number of accidents that occurred in September and April was the highest. In Hashemi Nazari's study (2012), a total of $34.43 \%$ of deaths due to traffic accidents occurred in summer, $26.69 \%$ in spring, $23.23 \%$ in autumn, and $15.64 \%$ in winter, and the highest incidence and frequency of death was observed in July [16]. In the study of Khatibi and Zarei, the most accidents occurred in summer, September [3, 21], and in the study of Koohpaei et al. between 2014 and 2016, the highest accident rate was in spring [14]. Also, in Asadi's research, most accidents were in summer [17]. All these studies are consistent with the present study, which could be due to holidays and increased travel in this season.

In the present study, the age group of 16 to 20 years had the highest rate of accidents, and the number of accidents was higher in men than women. According to the study of Khatibi et al. $73.7 \%$ of the accidents were related to men and $26.3 \%$ to women. Also, most of the accidents were related to 15 to 20 years old people [3]. According to Koohpaei et al.'s study, between 2014 and 2016, the highest accident rate was in the ages of 0 to 10 years [14]. Based on Zarei et al. study, the highest number of accidents $(60.93 \%)$ was related to men [21], all of which are similar to the present study results.

\section{Conclusion}

In this study, all accidents in 2018 were reviewed, and the existing data reference was valid, which is one of the strong points of this study and can help city managers for future planning to prevent accidents. However, due to the lack of complete records of some accidents, further studies can be done in this area. The results of the present study showed that "traffic accidents" and "falls from heights" are the most important emergencies that harm society. By focusing and assigning priorities on controlling these ac- 
cidents, health and safety policymakers can reduce a large portion of society's accidents.

\section{Ethical Considerations}

Compliance with ethical guidelines

This study was approved by the Ethics Committee of the Gonabad University of Medical Sciences (Code: IR.GMU. REC.1398.008).

\section{Funding}

This study has been registered as a Research Project (Ethics Code: IR.GMU.REC.1398.008) in Gonabad University of Medical Sciences, Vice-Chancellor for Research.

\section{Authors' contributions}

Supervision: Mohammad Hossein Beheshti, Mojtaba Emkani, Amin Zamani, Akram Tabrizi and Mostafa Jafari; Conceptualization: Mohammad Hossein Beheshti and Mostafa Jafari; Data analysis: Mohammad Hossein Beheshti, Akram Tabrizi and Mostafa Jafari; Writing - original draft: Mohammad Hossein Beheshti, Mojtaba Emkani and Amin Zamani, Mostafa Jafari, and Akram Tabrizi; Data collection: Amin Zamani; Methodology: Mojtaba Emkani.

\section{Conflicts of interest}

The authors declared no conflict of interest.

\section{Acknowledgements}

The authors express their gratitude and appreciation to Gonabad University of Medical Sciences Vice-Chancellor for Research. 
This Page Intentionally Left Blank 


\title{
بررسى فراوانى و علل انواع حوادث ثبتشده در مركز مديريت حوادث و فوريتهاى هزئشى

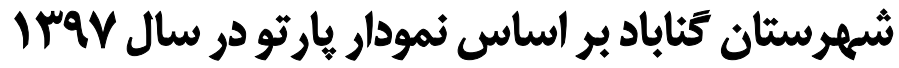

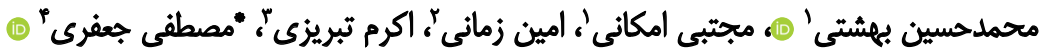

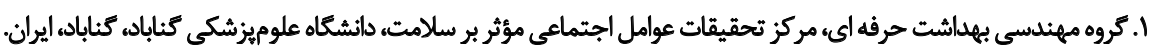

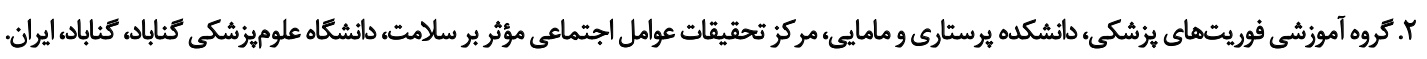

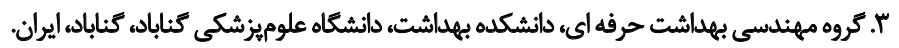

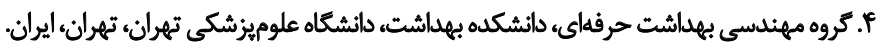

\section{حكS}

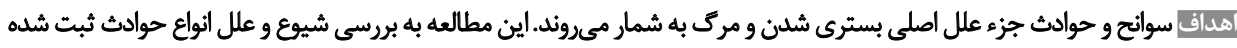

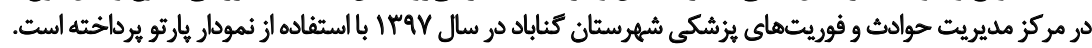

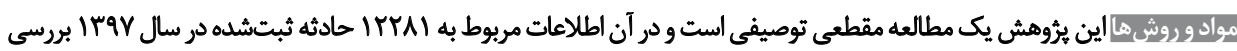

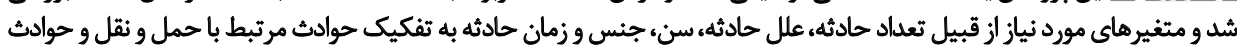

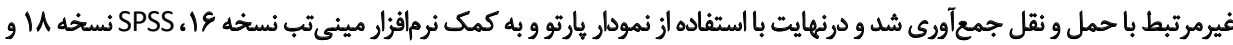
2010 EXCEL

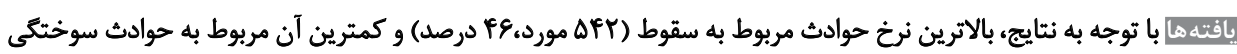

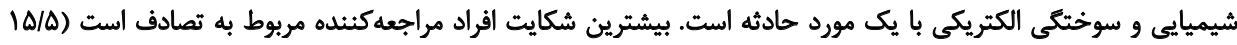

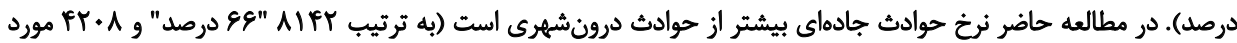

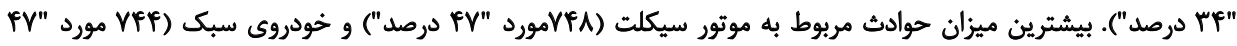

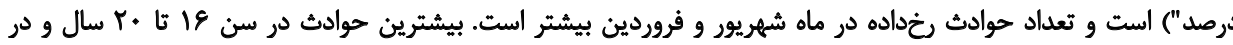
افراد مذكر است.

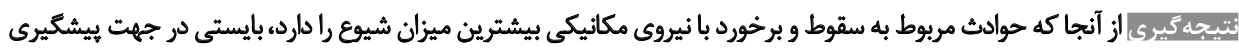

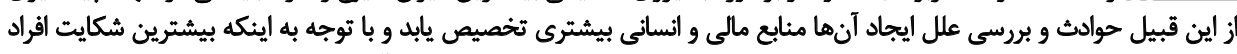

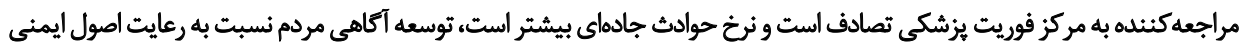

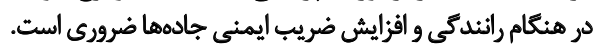

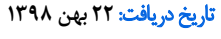

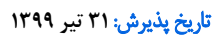

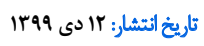

كليدوارهها:

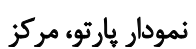
فوريت يزشكى، حوادث
\end{abstract}

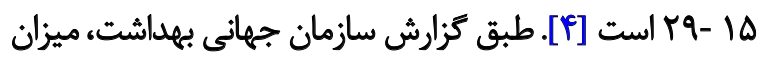

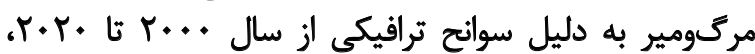
مقدمه

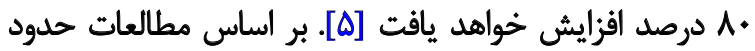

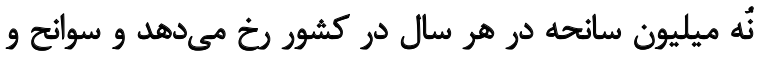

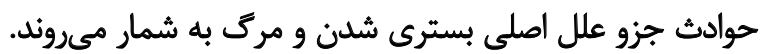

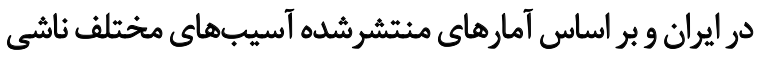

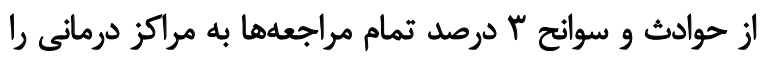

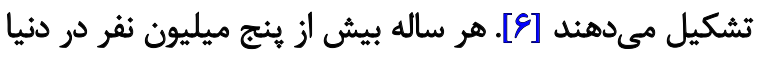

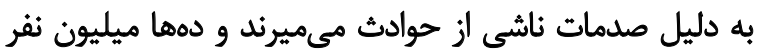

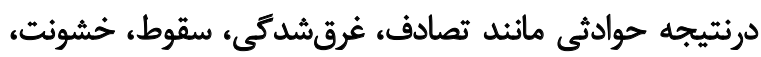

حوادث يكى از اساسىترين همه ميرىهاى بيمارىهاى

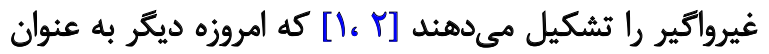

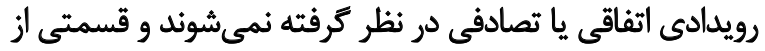

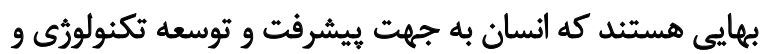

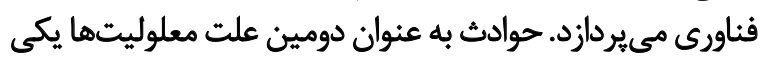

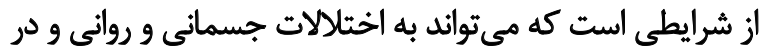

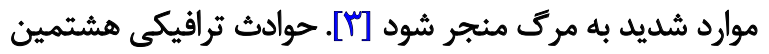

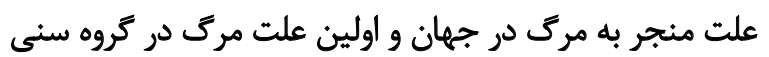




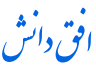

كرفت. نمودار يارتو درواقع توزيع فراوانى براى دادههاى وصفى

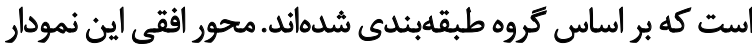

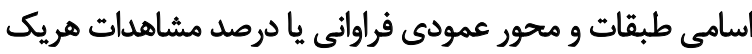

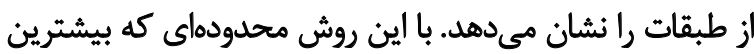

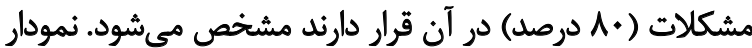

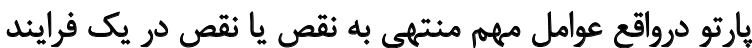

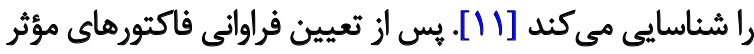

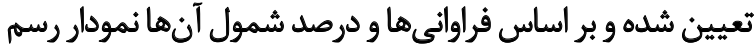

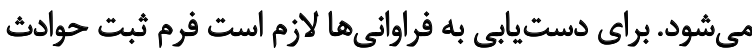

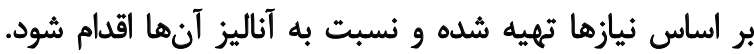

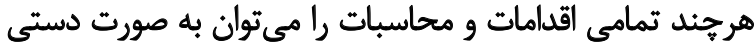

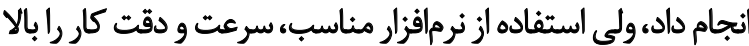
مىبرد. دو نرمافرزار معروف در اين زمينه SPSS و مينىتب است داست. در اين مطالعه اطلاعات مربوط به كليه حوادث ثبتشده در

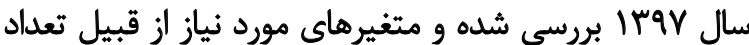

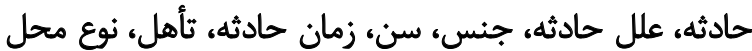

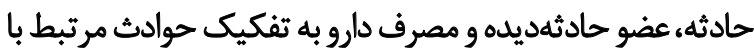

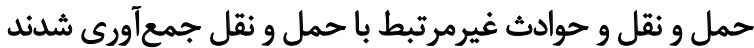

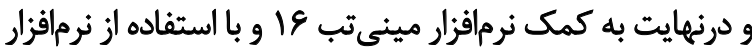
Sو 2010 EXCEL و نورد آناليز قرار كرفتئد.

يافتهها

بر اساس نتايج مطالعه حاضر به طور كلى در سال ون

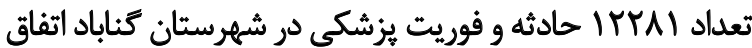

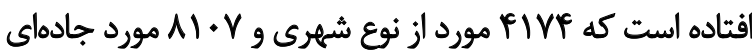

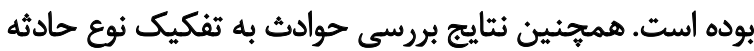

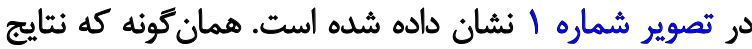

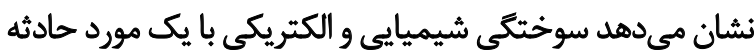

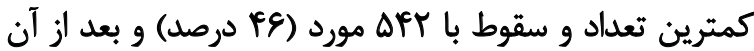

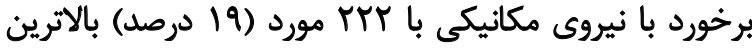
تعداد حادثه رابه خود اختصاص دانيك بادهاند.
برقگرفتكى، كَّش، خودكشى و غيره به مراكز فوريتهاى

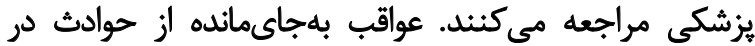

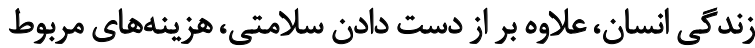

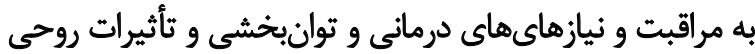

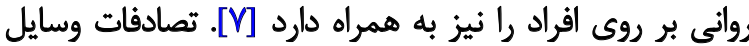

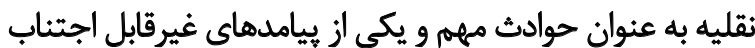

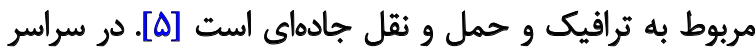

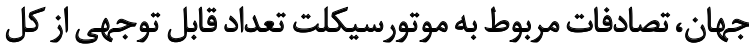

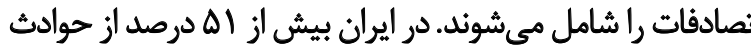

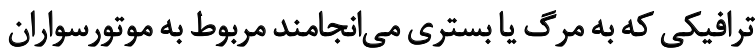

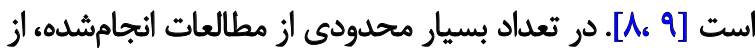

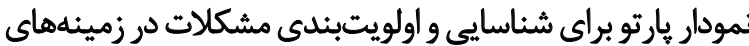

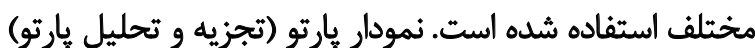

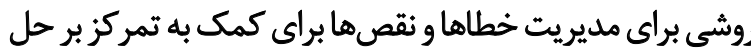

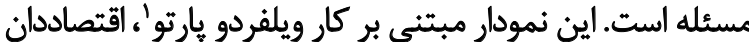

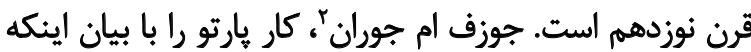

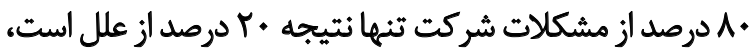

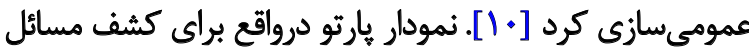

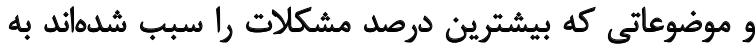

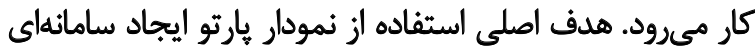

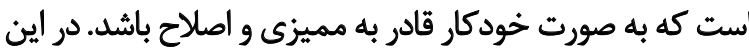

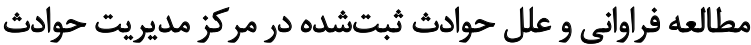

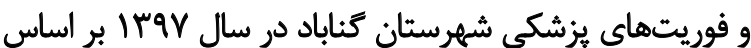
نمودار يارتو مورد بررسى قرار كرفت.

$$
\text { مواد ورشها نها }
$$

اين يُروهش يك مطالعه مقطعى توصيفى است كه در آن كليه

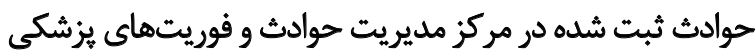

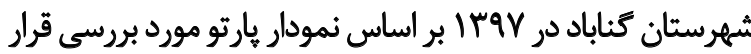

1. Vilfredo pareto

2. Joseph M. Juran 


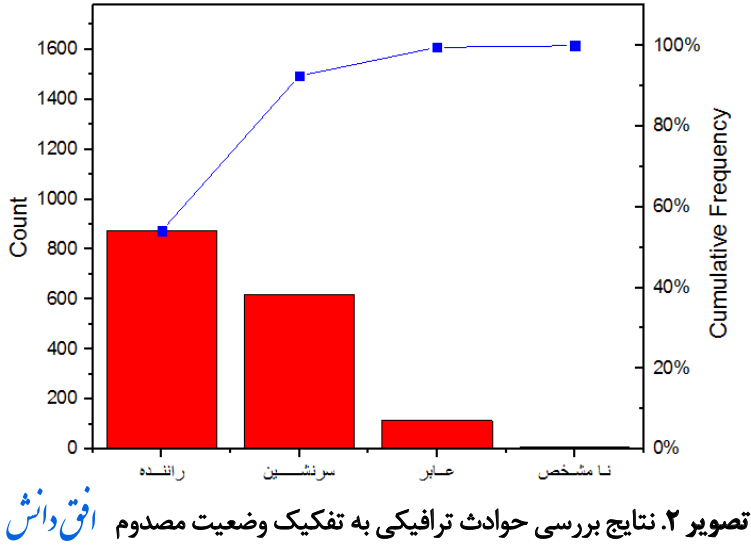

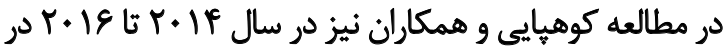

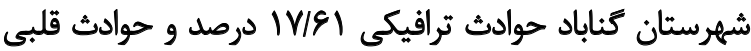

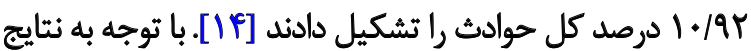

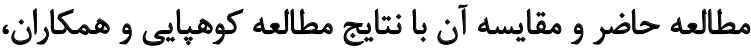

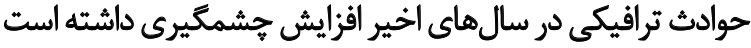

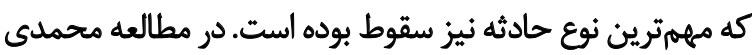

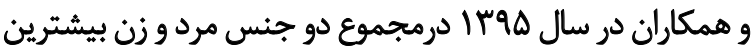

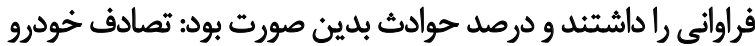

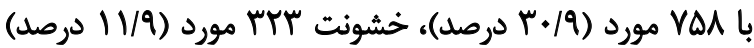

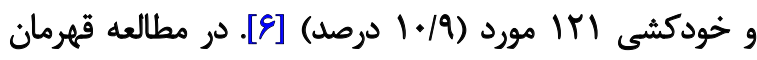

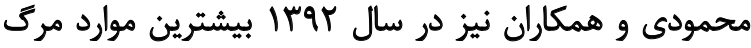

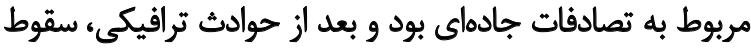

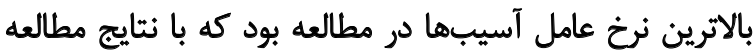

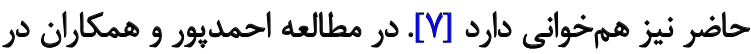

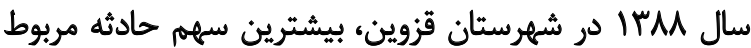

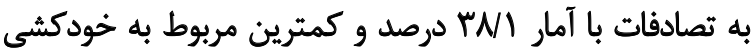

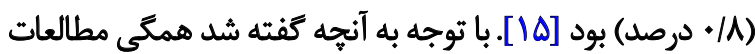

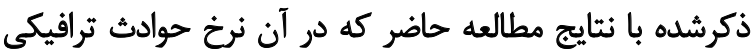

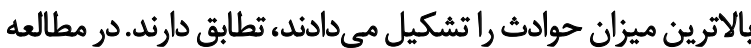

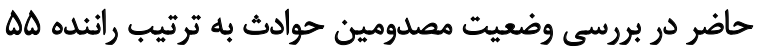

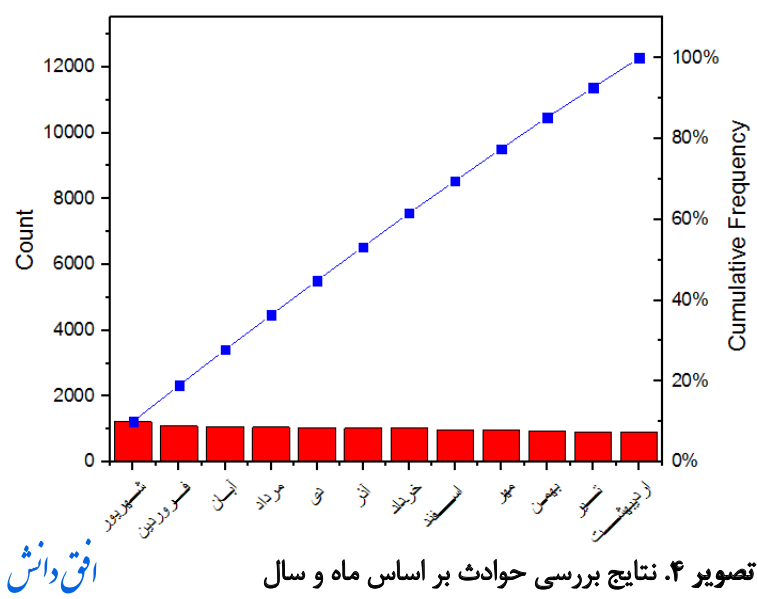

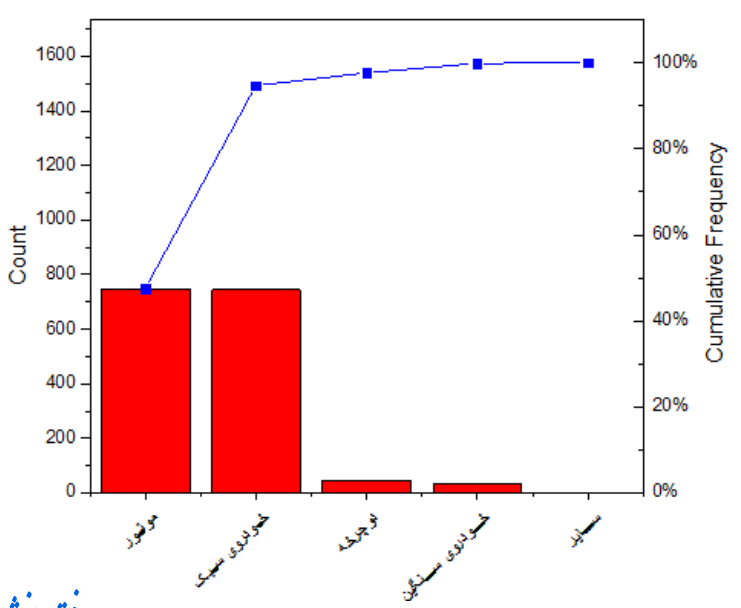

تصوير ب. نتايج بررسى حوادث ترافيكى به تفكيك نوع وسيله نقليه اقُوراتث نتايج بررسى حوادث ترافيكى به تفكيك وضعيت مصدوم در

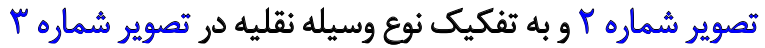
نشان داده شده است.

همجنين طبق تصوير شماره f نتايج نشان داد شهريور

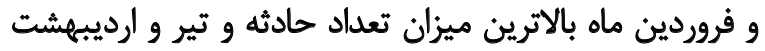

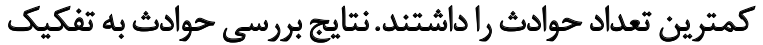

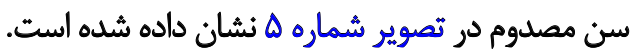
همجنين نتايج نشان داد بيشترين شكايت افراد مراجعه كننده

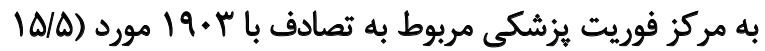

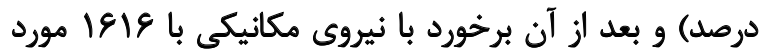

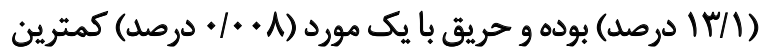

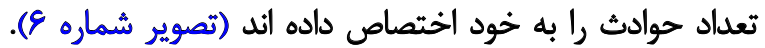

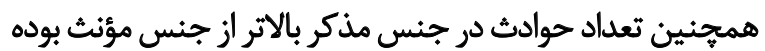

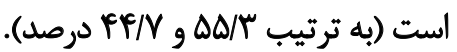

بحث با توجه به نتايج اين مطالعه بيش از •و درصد حوادث رخداديه

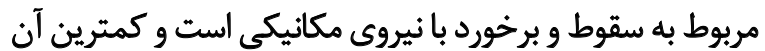

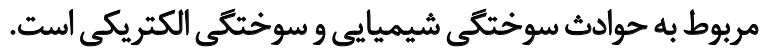

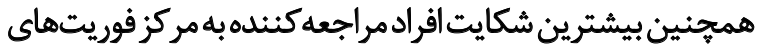

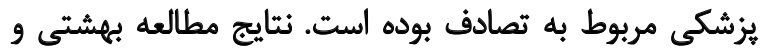

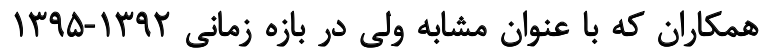

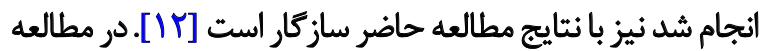

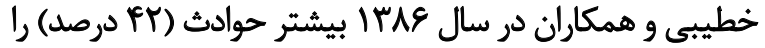

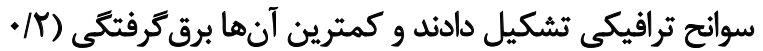

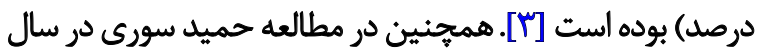

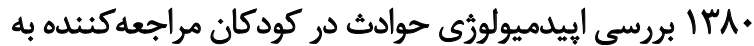

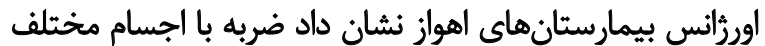
l (TV/T)

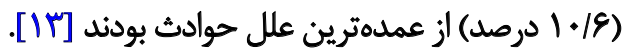




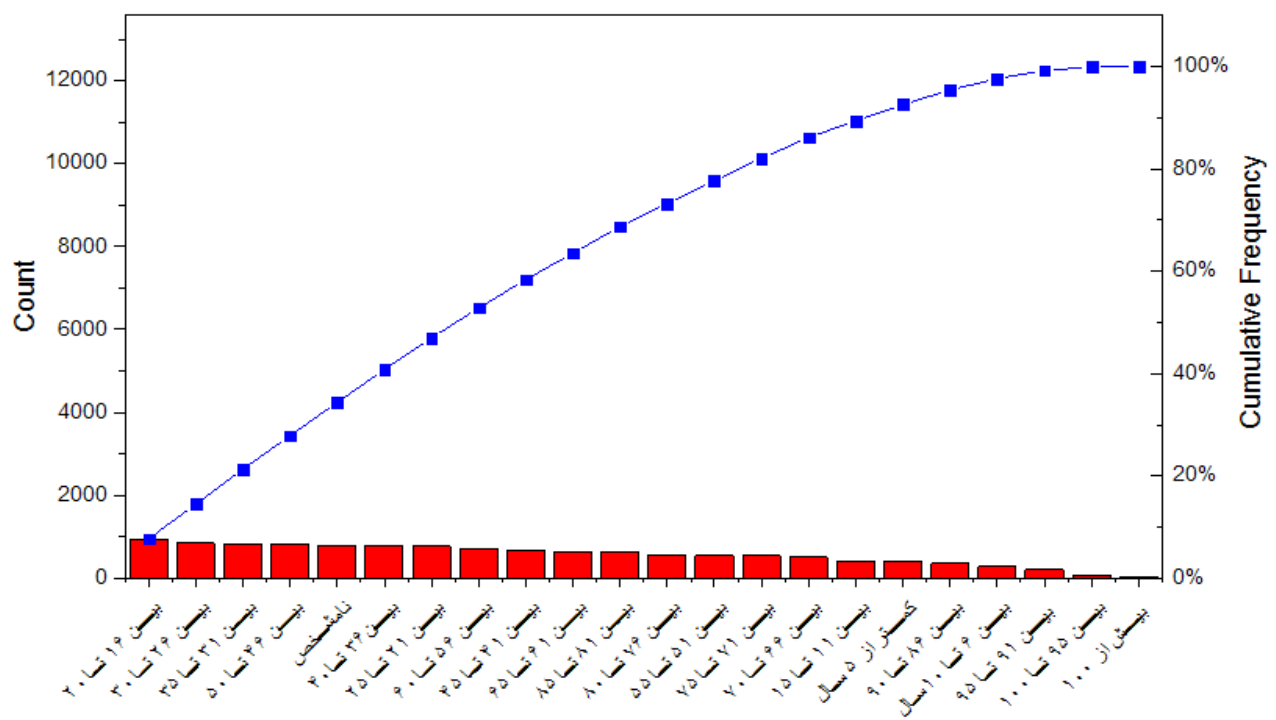

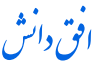

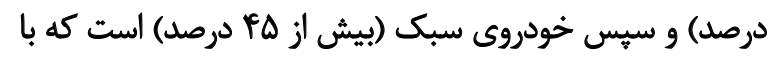

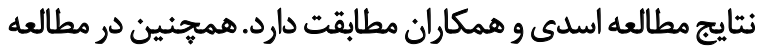

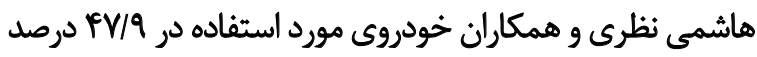

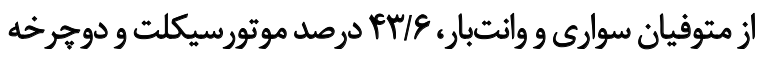

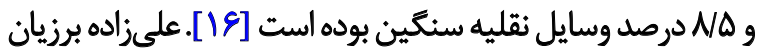

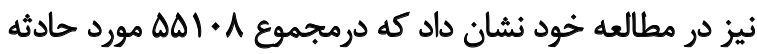

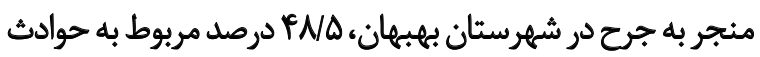

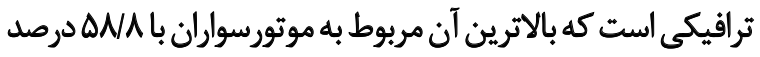

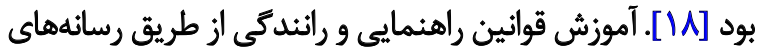
عمومى نقش بسزايى در افزايش آكاهى مردم دارد و آكاهيى مردم

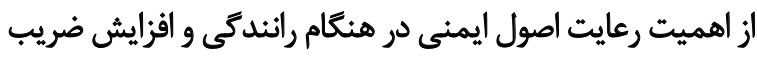

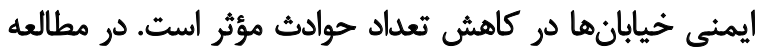

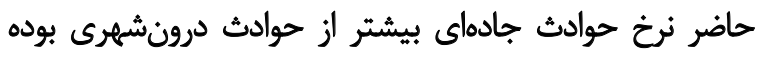

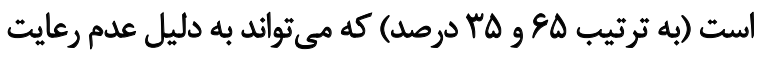

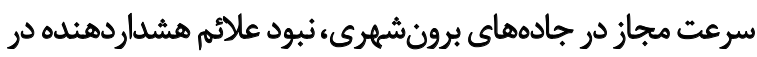

تصوير هـ نتايج بررسي حوادث به تفكيك سن مصدوم

درصد، سرنشين ·f درصد و عابر هياده A درصد آمار مصدومين

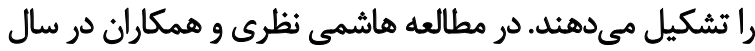

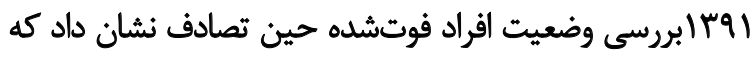

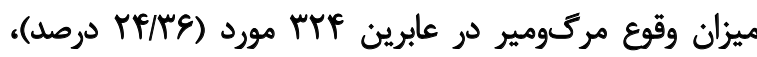

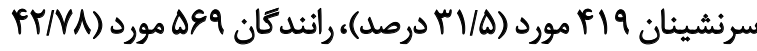

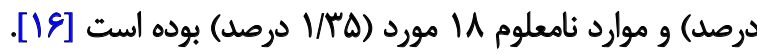

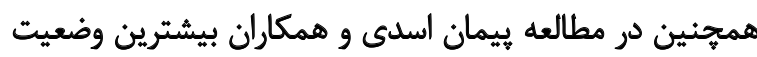

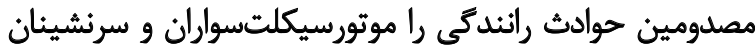

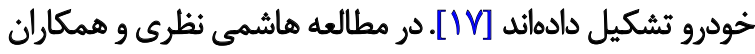

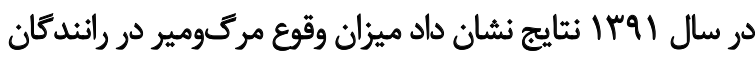

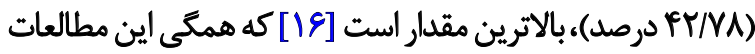

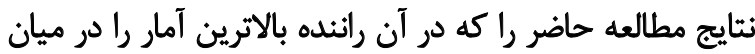
وضعيت مصدومين دارد، تأييد مي كنيند.

بيشترين ميزان حوادث مربوط به موتور سيكلت (بيش از

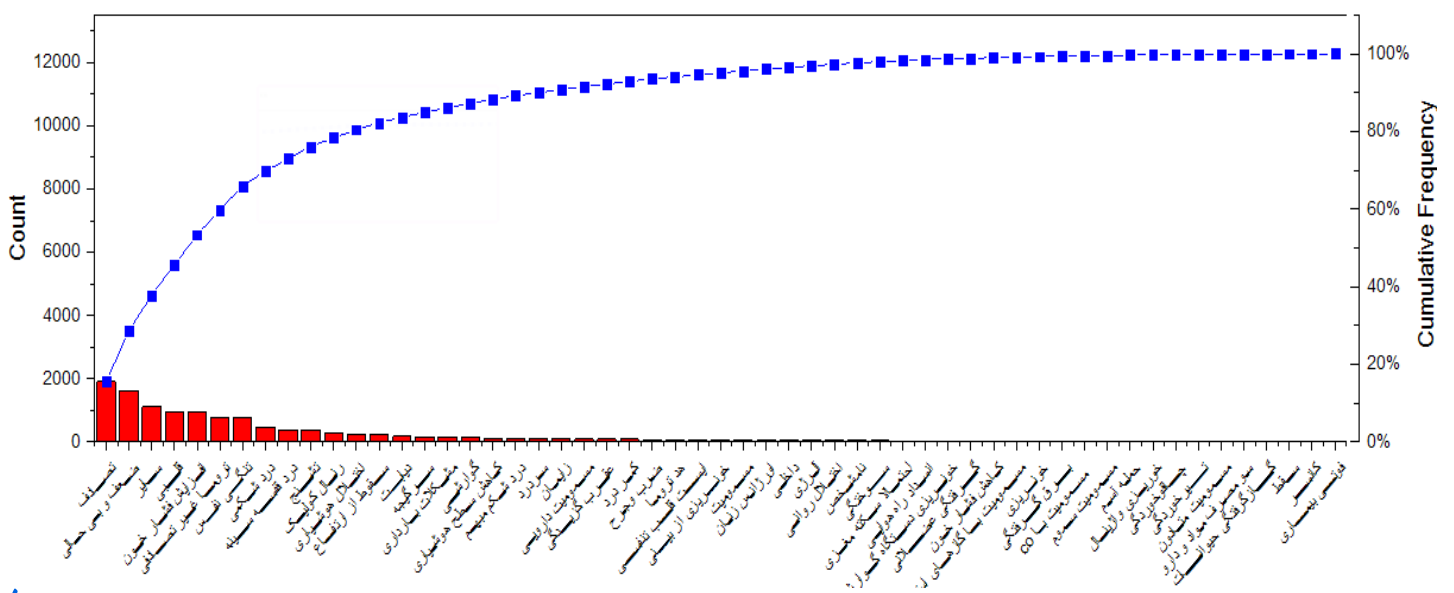

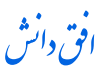

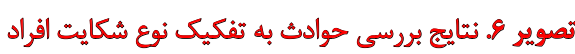




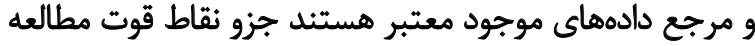

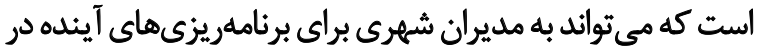

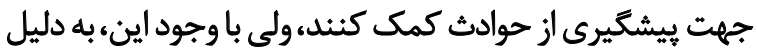

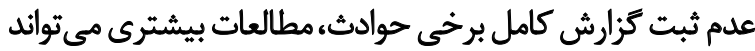

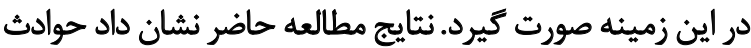

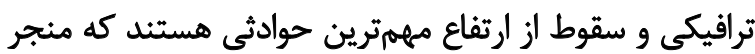

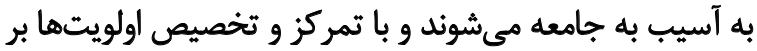

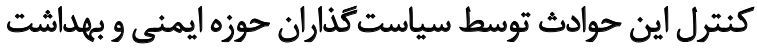
مى توان بخش زيادى از حوادث جامعه راكنترل كران كرد.

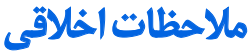

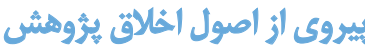

IR.GMU. اين مطالعه به عنوان طرح يثروهشى با كد اخلاق

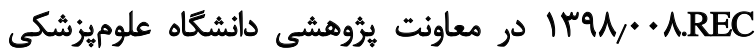

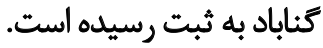

$$
\text { مامي مالى }
$$

حامى مالى اين يُروهش معاونت يُروهشى دانشعاه علوميزشكى

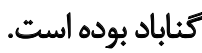

\section{مشاركت نويسئد مكان}

تأييد نسخه نهايى: محمدحسين بهشتى، مجتبى امكانى،

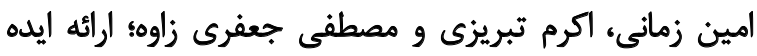

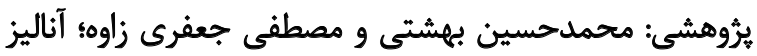

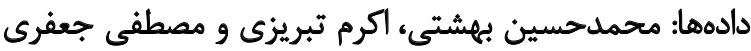

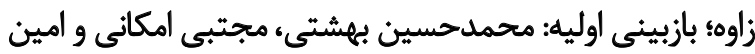

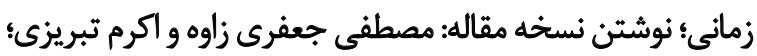
جمع آورى دادهها: امين زمانى؛ طراحى مطالعه: مجتبى امكانى. نمانى

$$
\text { تقارض منأق }
$$

بنابر اظهار هيجگونه تعارض منافع توسط نويسندكان بيان نشده است.

$$
\text { تشكر و قدورائي }
$$

نويسندكان مراتب تشكر و قدردانى خود را از معاونت يرؤوهشى

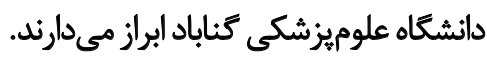

نقاط حادثهخيز، عدم استراحت كافى قبل از راندكّى و راندادى

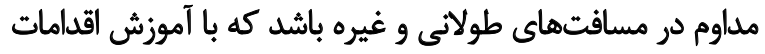

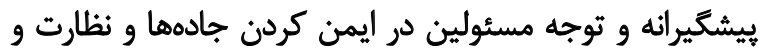

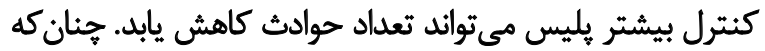

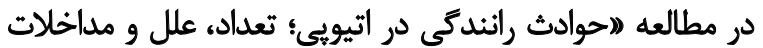

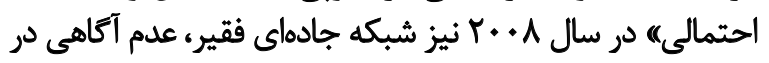

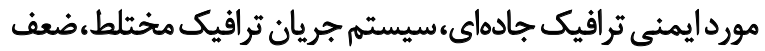

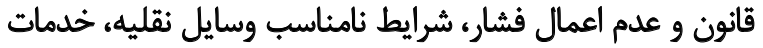

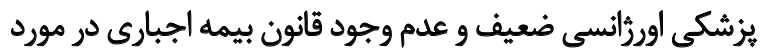

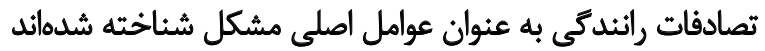

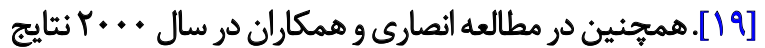

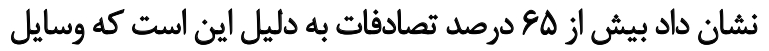

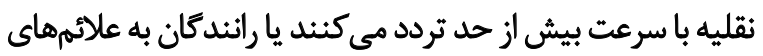

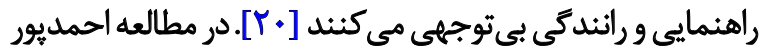

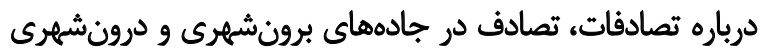

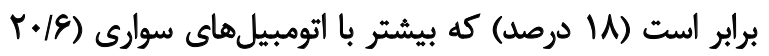

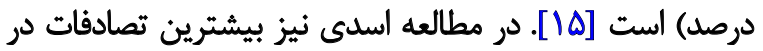

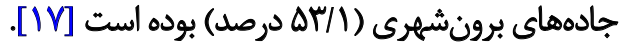

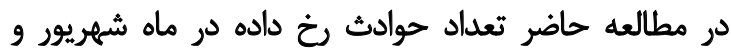

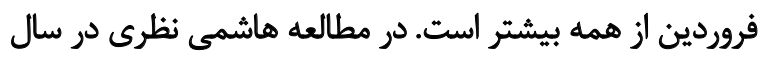

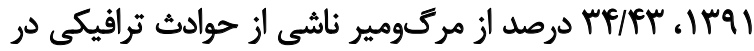

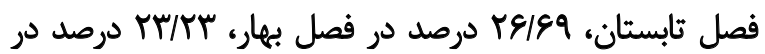

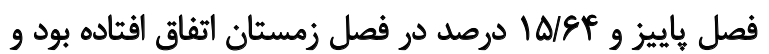

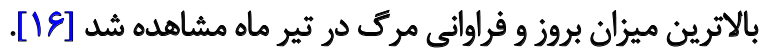

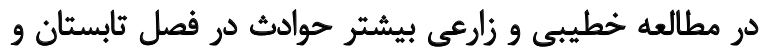

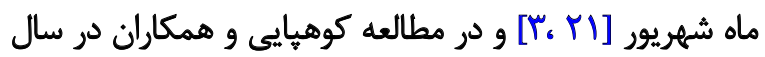

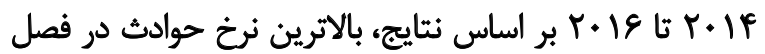

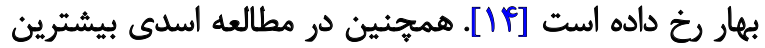

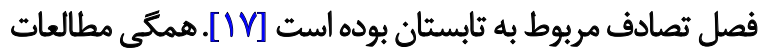

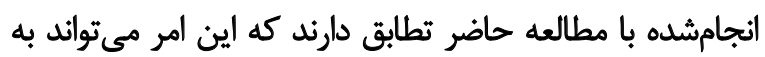

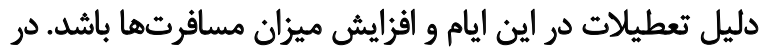

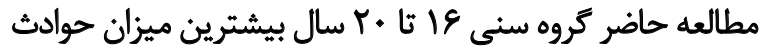

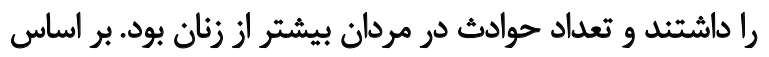

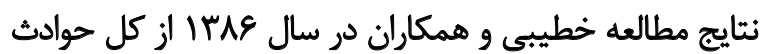

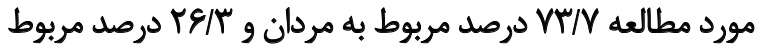

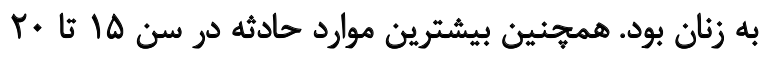

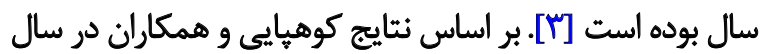

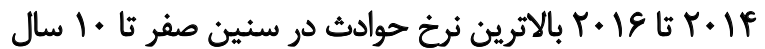

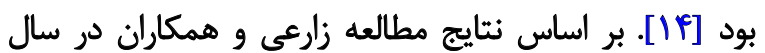

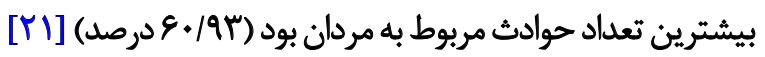
كه همكَ مشابه نتايج مطالعه حاضر هستيند. تنيجهئيرى اينكه در اين مطالعه كليه حوادث سال لوجr| بررسى شدهاند 


\section{References}

[1] Beheshti MH, Hajizadeh R, Mehri A, Borhani Jebeli M. [Modeling the result of hexane leakage from storage tanks and planning a emergency response programm in a petrochemical complex (Persian)]. Iran Occupational Health. 2016; 13(1):69-79. http://ioh.iums.ac.ir/ article-1-1450-en.html

[2] Hajizadeh R, Malakoti J, Beheshti MH, Khodaparast A, Mehri A, Akbaezadeh $A$, et al. [Epidemiological study of Qom construction accidents and provide an algorithm for accidents recordation (Persian)]. Iran Occupational Health. 2015; 12(2):70-8. http://ioh.iums.ac.ir/ article-1-1311-en.html

[3] Khatibi MR, Bagheri H, Khakpash M, Movahhed-Khalilabadi Z. [Prevalence and causes of hospitalization in victims admitted to emergency department of Imam Hossein hospital in Shahroud (Persian)]. Journal of Knowledge \& Health. 2007; 2(3):42-6. [DOI:10.22100/jkh. v2i3.247]

[4] Ghasemkhani M, Monazam MR, Abbasinia M, Mahmoodkhani S, Aghaee $H$, Asghari $M$, et al . [Assessment of fatigue and its relationship with Insomnia Severity Index in shift workers, fixed and rotating, Tehran rolling mills and steel production company (Persian)]. Iran Occupational Health. 2013; 10(2):79-86. http://ioh.iums.ac.ir/article1-691-en.html

[5] Abbasi M, Sadeghi M, Azami AA, Esmaeili SM, Kavousi J, Aryafard A. [Factors related to road traffic accidents leading to injury or death in Shahroud city (Persian)]. Journal of Safety Promotion and Injury Prevention. 2016; 4(2):83-90. [DOI:10.22037/meipm.v4i2.14132]

[6] Mohammadi M, Ahmadi A, Esmaeili A. [The frequency of accidents in Saqez in 2014: A short report (Persian)]. Journal of Rafsanjan University of Medical Sciences. 2017; 15(9):885-92. http://journal.rums. ac.ir/article-1-3574-en.htm

[7] Mahmodi Gh, Abdi Talarposhti M. [Assessing the prevalence of accidents leading to injury and death and its effective factors in selected hospitals of Mazandran in 2012 (Persian)]. Journal of Hospital. 2017; 16(2):70-81. http://jhosp.tums.ac.ir/article-1-5688-en.html

[8] Zamani Alavijeh F, Niknami Sh, Mohamadi E, Montazeri A, Ahmadi $F$, Ghofranipour $F$, et al. [High risk behaviors among Iranian motorcyclists: A qualitative study (Persian)]. Payesh. 2010; 9(3):269-78. http://payeshjournal.ir/article-1-565-en.html

[9] Baqiani Moghaddam MH, Halwani GH, Ihram Posh MH. [Investigation of personality type and accident status in motorcyclists in Yazd City, 2004 (Persian)]. Journal of Mazandaran University of Medical Sciences. 2006; 16(51):69-75. https://www.sid.ir/fa/journal/ViewPaper.aspx?ID=44104

[10] Siregar I, Nasution AA. Component identification the causes of machinery damage in pharmacy company using Pareto diagram. IOP Conference Series: Materials Science and Engineering. 2018; 420:012139. [DOI:10.1088/1757-899X/420/1/012139]

[11] Wilkinson L. Revising the Pareto chart. The American Statistician. 2006; 60(4):332-4. [DOI:10.1198/000313006X152243]

[12] Beheshti M, Rahat R, Davoodi A, Hoseon Alizadeh F, Azrah K, Hajizadeh R. [Investigation of the most important direct cause of occupational accidents based on the Pareto chart (Persian)]. Iran Occupational Health. 2015; 12(3):38-45. http://ioh.iums.ac.ir/article1-1388-en.html

[13] Surrey $H$. [An epidemiologic study of traffic accidents in children admitted to the emergency hospital in Ahvaz (Persian)]. Jundishapur Medical Scientific Journal. 2003; 32:1-11. https://www.sid.ir/fa/journal/ViewPaper.aspx?ID=10731
[14] Beheshti MH, Hajizadeh R, Farhang Dehghan S, Aghababaei R, Jafari SM, Koohpaei AR. Investigation of the accidents recorded at an emergency management center using the Pareto chart: A crosssectional study in Gonabad, Iran, during 2014-2016. Health in Emergencies \& Disasters Quarterly. 2018; 3(3):143-50. [DOI:10.29252/ nrip.hdq.3.3.143]

[15] Ahmadpour A, Bigdeli R, Ghouchi Z, Karbord AA, Ahmadi S. [Investigation of the trend and prevalence of accidents in Qazvin city in 2009 (Persian)]. Edrak. 2010; 5(19):38-42. http://www.qums.ac.ir/portal/ file/?128826/196.pdf

[16] Erfanpoor S, Hashemi Nazari SS, Ghadirzadeh MR. [An epidemiology study of fatal road traffic accidents in Khorasan Razavi province in 2011 (Persian)]. Medical Journal of Mashhad University of Medical Sciences. 2017; 59(4):261-8. https://mjms.mums.ac.ir/? action=article \&kw=16952

[17] Monsef Kasmayi V, Assadi P, Maleki Ziabari SM. [The epidemiologic of the traffic accidents helped by EMS, Guilan 2011-2013 (Persian)]. Scientific Journal of Forensic Medicine. 2014; 20(2):55-60. http://sjfm.ir/ article-1-583-en.htm

[18] Parvin S, Daneshi N, Jamshidi M, Alizadeh Barzian M, Alizadeh Barzian K. [An epidemiologic study of traffic accidents in Behbahan cty during 2006-2014 (Persian)]. Journal of Health Research in Community. 2017 3(3):46-57. http://jhc.mazums.ac.ir/article-1-238-en.htm

[19] Persson A. Road traffic accidents in Ethiopia: Magnitude, causes and possible interventions. Advances in Transportation Studies International Journal. 2008; 15:5-16. http://www.atsinternationaljournal.com/index. php/2008-issues/xv-july-2008/414

[20] Ansari S, Akhdar F, Mandoorah M, Moutaery K. Causes and effects of road traffic accidents in Saudi Arabia. Public Health. 2000; 114(1):37-9. [DOI:10.1016/S0033-3506(00)00306-1]

[21] Zarei E, Dormohammadi A. [Accidents analysis in a disaster and emergency medical management center (Persian)]. Journal of Safety Promotion and Injury Prevention. 2015; 3(3):191-98. https://journals.sbmu. ac.ir/spip/article/view/7769 
This Page Intentionally Left Blank 